Relations industrielles

Industrial Relations

\title{
Enquête sur le prolétariat
}

\section{Gérard Dion}

Volume 3, numéro 5, janvier 1948

URI : https://id.erudit.org/iderudit/1023593ar

DOI : https://doi.org/10.7202/1023593ar

Aller au sommaire du numéro

Éditeur(s)

Département des relations industrielles de l'Université Laval

ISSN

0034-379X (imprimé)

1703-8138 (numérique)

Découvrir la revue

Citer ce document

Dion, G. (1948). Enquête sur le prolétariat. Relations industrielles / Industrial

Relations, 3(5), 73-73. https://doi.org/10.7202/1023593ar

Tous droits réservés @ Département des relations industrielles de l’Université Laval, 1948
Ce document est protégé par la loi sur le droit d'auteur. L'utilisation des services d'Érudit (y compris la reproduction) est assujettie à sa politique d'utilisation que vous pouvez consulter en ligne.

https://apropos.erudit.org/fr/usagers/politique-dutilisation/ 
to their favorite radio program during the lunch hour. Employees meeting with accident or falling sick during working hours have a nurse at their disposal, and may at any time have a free consultation with the Company doctor, who spend the whole of every forenoon in the plant. Fist-aid medicaments are supplied gratis; and shoud remedies, tonics or glandular extracts be required, the Company buy them for the employee, who makes reimbursement in small weekly installments. The same privilege is available as to the service offered by our two dentists at fixed rates, the fees being payable by the Company and reimbursable by the employee at the rate of two dollars a week. Every examination whether medical, dental or of vision, is at the exclusive charge of the employer, as is also the consultation; but the services do not stop there.

Employees are at full liberty to state their grievances to the management, lodge complaints, and request assistance and counsel on any question of a personal, family, social or other nature. One and all are treated with courtesy, equality and justice. In this way the employees come to feel that they belong to one big family where it is good to work; for it is a «family 》 brand of discipline which reigns in our plant, the employer being ever happy to safeguard the physical and moral health of the future mothers of our race.

We might well touch also on sports and social organizations encouraged by the Company, but let us pass that by for the moment.

It might fittingly be asked what result has been obtained by this system, and what the approximate cost of these services can amount to.

We'have no fear of stating that the rate of our labour turnover is one of the lowest in the Province of Quebec, varying as it does from $0.8 \%$ to $4 \%$, with an average of $1.5 \%$, which represents a real saving in the cost of school and training. Next, the rate of absenteeism is only $2.7 \%$ in the avoidable category, with a difference of only $1 \%$ in that of absences which are unavoidable, all of which constitutes a record in big industry in Quebec. A third result obtained is that the health of our workers has risen to a level higher than that of the average in industry; and in our plant it is the exception for an employee to bear the taint of «industrial or factory pallor. » A fourth result, flowing of the former ones, is the stability of the force of experienced workers, which facilitates the earning of higher wages without any spurring on for greater output. And all this is readily understood when it is realized that the work is performmed in a clean and inviting environment, where every human factor, as well as the personnality of each individual, is taken into account.

For an industry employing nearly a thousand persons, it goes without saying that the organization and upkeep of such services necessitate an expense of some thousands of dollars, or an annual average of fifteen dollars per employee, for medical service alone. The secret of such success lies in frank collaboration between the management and the doctor, based on the progressive education of the working force. The person responsible to the Company management for the carrying out of this policy is the personnel manager. He has his own budget to administer, and upon him devolves the duty of maintaining a due and proper harmony in the establishment. In a small enterprise this responsability will be combined with that of sales, purchasing, financing or general management.

If one of our enterprises has succeeded in lowering the rate of labour turnover to a strict minimum by the oganization of medical, industrial and social services, why should not others follow along the same path? The success of industry depends upon it, to say nothing of how such a line of conduct promotes good understanding amongst the different classes of society.

\section{ENQUETE SUR LE PROLÉTARIAT}

Dans sa livraison de novembre, la revue l'Action Nationale commence la publication d'une enquête sur le prolétariat canadien-français. "L'existence et la montée d'un prolétariat canadien-français suscitent des problèmes dans tous les ordres, mais particulièrement dans celui de la nation». On y ajoute \& ce n'est pas un thème pour exercice littéraire... Les ouvriers sont devenus la majorité dans la nation. Ils sont en même temps, de par les circonstances, le milieu social le moins enclin à reconnaître les implications du national. Pourquoi en est-il ainsi? Peuton agir sur les causes, dont cet état intellectuel et affectif est la conséquence?

Cette revue invite tous ceux que leur expérience et leur réflexion ont familiarisé avec la question de lui fiaire parvenir leur point de vue. Déjà des témoignages de milieux très différents ont été publiés, celui de M. Esdras Minville, directeur de l'Ecole des Hautes Etudes Commerciales, celui de M. Guy Cormier, rédacteur en chef du Front Ouvrier, et enfin celui de $M$. Gérard Picard, président général de la C.T.C.C.

Ce problème est très important pour tous ceux qu'intéressent les relations du travail. C'est un fait que personne ne peut dédaigner par quelque motif que ce soit: les industriels, les chefs ouvriers de la province de Québec, de quelque nationalité qu'ils soient, ont à déployer leur action dans un milieu canadien-français. Nous encourageons donc nos lecteurs à prendre connaissance de ces analyses et même à répondre à l'appel de cette revue en lui faisant part de leurs propres observations. - G.D. 